\title{
Proyeksi EXIT Chart untuk Memprioritaskan Data Komunikasi Manusia pada Jaringan Super Padat
}

\author{
KHOIRUN NI'AMAH, SOLICHAH LARASATI
}

\author{
Program Studi S1 Teknik Telekomunikasi Institut Teknologi Telkom Purwokerto
}

Email: irun@ittelkom-pwt.ac.id

Received 8 Juni 2019 | Revised 15 Juli 2019 | Accepted 18 Agustus 2019

\begin{abstract}
ABSTRAK
Penelitian ini dilakukan untuk menguji jaringan masa depan dengan melibatkan ribuan mesin. Teknik Coded Random Access (CRA) akan dijadikan bagian penting pada teknologi komunikasi seluler generasi ke-5 (5G) tahun 2020 yang diprediksi data komunikasi manusia bercampur dengan mesin. CRA pada penelitian ini dipandang sebagai skema multiple access terbaru yang memanfaatkan coding (repetition dan MDS codes), penelitian ini berdasarkan repetition codes untuk mendesain sub-optimal degree distribution pada grup manusia dan mesin. Kinerja sistem dievaluasi menggunakan parameter proyeksi Extrinstric Information Transfer (EXIT) chart, throughput, dan packet-loss rate (PLR). Sub-optimal degree distribusi untuk grup manusia $((3,1), 0.3,(8,1), 0.7)$, grup mesin $((2,1), 0.6$, $(4,1), 0.4)$. Throughput grup manusia tanpa fading 0,775 paket/slot dengan fading 0,736 paket/slot dan grup mesin tanpa fading 0,669 paket/slot dengan fading 0,646 paket/slot. Kontribusi penelitian ini sangat signifikan karena data pada komunikasi manusia dapat diprioritaskan yang dilihat dari kinerja deteksi paket yang diterima tanpa error (throughput) pada grup manusia lebih tinggi dibanding mesin.
\end{abstract}

Kata kunci: Repetition codes, EXIT Chart, Degree Distribusi, Manusia, Mesin.

\begin{abstract}
This research considers future super-dense networks. Coded Random Access (CRA) technique is expected to be important in fifth generation (5G) celullar communication in 2020 predicted that human data communication are mixed with machines. CRA as a new multiple accesss sheme which exploiting coding (repetition and MDS codes), this research is based on repetition codes for design sub-optimal degree distribution for human and machines groups. The performance of prioritized are evaluated based on parameters, e.g., projection Extrinsic Information (EXIT) chart, throughput, and packet-loss rate (PLR). Sub optimal degree distribution human $((3,1), 0.3,(8,1), 0.7)$, machines $((2,1), 0.6,(4,1), 0.4)$. Throughput human without fading 0,775 packet/slot with fading 0,736 packet/slot and machine without fading 0,669 packet/slot with fading 0,646 packet/slot. The contribution of this research is significant because the data on human communication can be prioritized as seen from the performance of correctly received packets (throughput) in the human group is higger than machines.
\end{abstract}

Keywords: Repetition Codes, EXIT Chart, Degree Distribution, Human, Machines. 


\section{PENDAHULUAN}

Pada tahun 2020 akan dihadirkan paradigma baru teknologi telekomunikasi nirkabel generasi ke-5 (5G), komunikasi tidak hanya diperlukan oleh manusia tetapi juga oleh mesin (machines) yaitu Internet-of-Things (IoT). IoT melibatkan komunikasi yang sangat besar (massive) karena saat itu jumlah mesin yang akan terkoneksi ke internet diperkirakan mencapai 30 milyar, bahkan sampai 50 milyar (Ericsson, 2011), padahal jumlah penduduk dunia sekitar 5 milyar. Dengan asumsi bahwa 50 milyar ini benar terjadi, maka manusia hanya 1/10 bagian dalam jaringan tersebut. Gambar 1 menjelaskan fenomena ini.

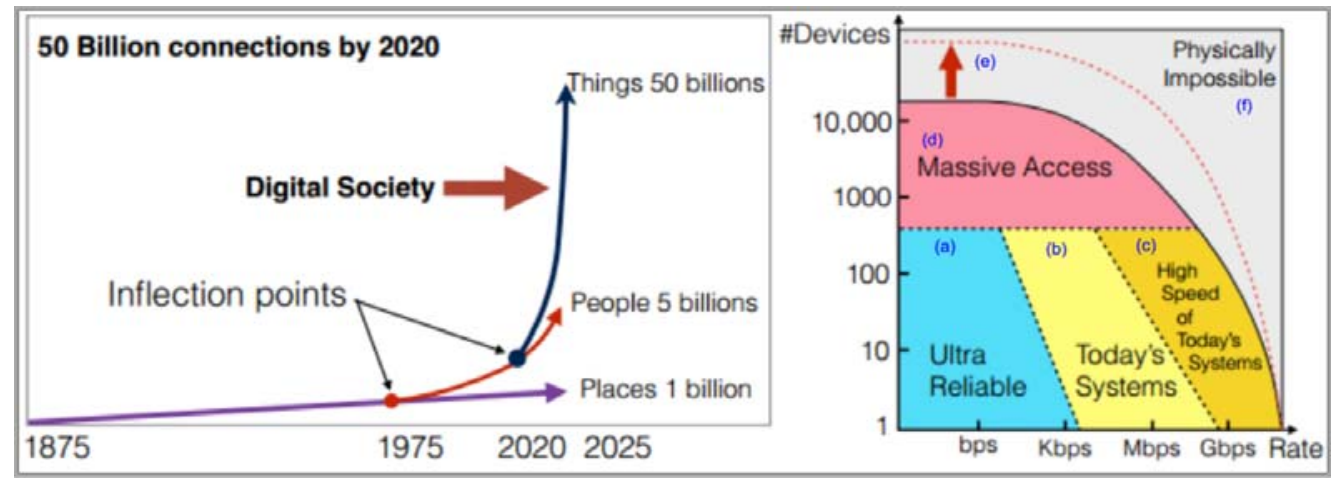

\section{Gambar 1. Prediksi Meningkatnya Jumlah Mesin yang Sangat Besar pada Tahun 2020 dan Hubungan Antara Teknologi Masa Kini dan Masa Depan Berdasarkan Bit-rate dan Jumlah Mesin (Ericsson, 2011)}

Generasi 5G mensyaratkan setidaknya ada triangle requirement Internasional Telecommunications Union-Recommendation (ITU-R) (ITU, 2015), yaitu (i) enhanced mobile data rate, (ii) massive machine-type communications, dan (iii) ultra-reliable and low latency communications. Masalah pada massive machine-type communications diselesaikan pada penelitan ini karena jumlah komunikasi mesin yang sangat besar maka perlu dilakukan prioritas pada data komunikasi manusia dibandingkan data komunikasi mesin. Keberhasilan komunikasi manusia perlu diutamakan, terutama jika komunikasi tersebut adalah komunikasi darurat seperti komunikasi petugas di mobil ambulan dengan dokter rumah sditakit tujuan, atau komunikasi institusi pertahanan dan keamanan negara, seperti kepolisian, TNI, karena menyangkut keamanan masyarakat dan negara. Komunikasi seperti ini tidak boleh lebih buruk dibandingkan dengan komunikasi antar mesin, misalnya komunikasi suhu, sensor mobil di tempat parkir, sensor lampu otomatis rumah orang yang ditinggalkan pemiliknya ke luar kota. Data komunikasi antar manusia perlu diprioritaskan pada teknologi komunikasi 5G masa depan.

Jaringan komunikasi super padat berimbas pada lalu lintas pertukaran data yang terjadi dalam jaringan, hal ini mendesak untuk munculnya sebuah teknik multiple access baru yaitu teknik multiple access CRA, karena teknologi sebelumnya, misalnya, Time Division Multiple access (TDMA), Frequency Division Multiple access (FDMA), Code Division Multiple Access (CDMA) yang memerlukan transmit schedulling, tidak mampu memberikan solusi dalam menangani atau melayani jumlah user yang sangat banyak pada jaringan super padat (super-dense network) (Anwar \& Hasan, 2015).

Jumlah user dan machines yang sangat besar memerlukan teknologi multiple access yang sesuai dan handal. Teknik multiple access Coded Random Access (CRA) sangat sesuai dengan jaringan wireless super padat (wireless super-dense networks) di masa depan karena 
diperkirakan sulitnya melakukan schedulling untuk jumlah devices yang mencapai ribuan. Cara termudah adalah dengan random access, sehingga setiap user atau device dapat memilih time -slot manapun secara random tanpa diperlukan penjadwalan (schedulling). CRA merupakan salah satu teknik multiple access yang merupakan kombinasi antara random access dan channel coding. CRA melakukan transmit data secara random karena user bebas dalam memilih time-slot yang dituju dimana jumlah user lebih sedikit daripada jumlah time -slotyang tersedia untuk menjamin adanya time-slot yang memiliki degree satu atau user yang terdeteksi. CRA mempunyai dua kata kunci, yaitu random dan koding, dengan bantuan successive interference cancellation (SIC) untuk menghindari tabrakan data (interferensi). (Anwar \& Hasan, 2015).

Beberapa teknik pengkodean pada penelitian sebelumnya seperti pada penggunaan Convolutional Codes, Block Codes, Turbo Code, Low Density Parity Check (LDPC) dan Low Density Generator Matrix (LDGM) dinilai masih belum bisa memenuhi kebutuhan pada massive machines-type communication karena memiliki rate yang tetap (tidak fleksibel) dan cukup kompleks. Permasalahan mengenai massive-type communication telah diselesaikan dengan menggunakan teknik multiple access CRA yang dapat melayani jutaan user (Liva, 2011). Peneliti (Anwar \& Hasan, 2015) mengusulkan teknik baru dengan menggunakan repetition codes untuk mendeteksi user dengan jumlah yang sangat besar dan degree distribution yang diusulkan sudah cukup optimal namun belum ada pembagian grup atau memberikan prioritas pada data komunikasi manusia, peneliti (Toni \& Frossard, 2015) melakukan validasi antara teori dan simulasi untuk pembagian antara kelas yang diprioritaskan dan kelas yang tidak diprioritaskan dengan menggunakan kode Irregular Repeitition Slotted ALOHA (IRSA). Jumlah user yang semakin banyak (massive) menyebabkan data antara komunikasi manusia dan mesin bercampur menjadi satu, sehingga pada penelitian ini dilakukan prioritas pada data komunikasi manusia.

Pada penelitian ini menggunakan teknik multiple access CRA berdasarkan repetition codes dan membagi user menjadi dua bagian yaitu grup manusia dan grup mesin dengan tujuan untuk memperioritaskan data komunikasi manusia dibandingkan data komunikasi mesin yang menjadi urgent didalam jaringan $5 \mathrm{G}$ dan jaringan super padat, karena bercampurnya seluruh data dalam jaringan super padat maka diperlukan sub-optimal degree distribution pada grup manusia dan mesin menggunakan bantuan proyeksi EXIT chart.

\section{METODOLOGI PENELITIAN}

\subsection{Model Sistem Penelitian}

Pada masa mendatang jaringan telekomunikasi wireless diprediksi akan memiliki tingkat lalu lintas pertukaran data yang padat seperti yang ditunjukkan pada Gambar 2 terutama link antara user dengan base station (BS). Sejumlah user dari $u_{1}$ hingga $u_{M}$ (manusia dan mesin) transmit paket ke BS untuk selanjutnya masuk ke jaringan internet. Jumlah transmisi dari user ke BS dibentuk dari degree distribution. 


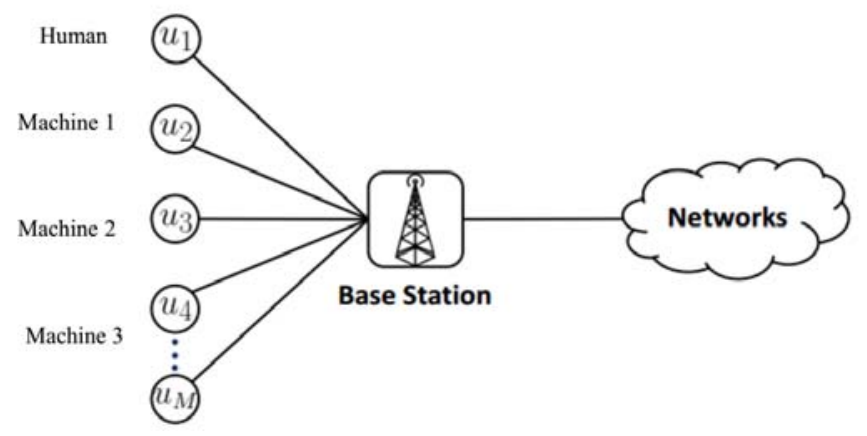

\section{Gambar 2. Struktur Jaringan Super Padat (Super-dense Network) dengan Jumlah User yang Sangat Besar}

Sistem model pada penelitian ini diilustrasikan pada Gambar 3 yaitu sejumlah user dibagi menjadi dua grup manusia dan mesin (human and machine groups) sama-sama mengakses time -slot secara bebas dan acak (random). Lingkaran mewakili user node (UN) yang memiliki degree $\ell$ sedangkan kotak mewakili slot node (SN) yang memiliki degree $d$. Erasure probability yang keluar dari usermanusia direpresentasikan dengan $q^{h}$ dan erasure probability yang keluar dari time -slot manusia adalah $p^{h}$, sama halnya dengan grup mesin $q^{m}$ dan $p^{m}$.

Grup manusia ditunjukkan dengan $U_{h}=U_{1}^{H}$ dan grup mesin $U_{m}=\left\{U_{1}^{M}, U_{2}^{M}, \ldots \ldots, U_{9}^{M}\right\}$ dan total time-slot $T=\left\{t_{1}, t_{2}, \ldots t_{20}\right\}$. Untuk memprioritaskan grup manusia dilakukan dengan memberikan kebebasan kepada grup manusia untuk mengakses semua time -slot sementara pada grup mesin hanya dapat mengakses sebagian time -slot saja. Sesuai dengan sistem model pada penelitian ini pada Gambar 3 grup manusia dapat mengakses semua time-slot $\left(t_{1}-t_{20}\right)$ sebanyak 20 time -slot dan grup mesin hanya dapat mengakses 18 time -slot $\left(t_{3}-\right.$ $\left.t_{20}\right)$. Target dari skema CRA dengan prioritas ini adalah untuk memaksimalkan jumlah user $M$, pada penelitian ini jumlah user $M$ sangat besar karena terdapat dua grup sementara pada penelitian (Anwar \& Hasan, 2015) hanya satu grup saja, sehingga ada penelitian ini total seluruh user penjumlahan dari grup manusia dan mesin $M=M_{h}+M_{m}$ dan pada CRA sebisa mungkin meminimalkan jumlah time -slot $N\left(N_{m}<N_{h}\right)$ sehingga nilai $G$ (offered traffic) menjadi maksimal. Pada penelitian ini offered traffic $(G)$ grup manusia dan mesin dapat dimaksimalkan karena merupakan penjumlahan dari offered traffic grup manusia dan mesin berbeda dengan penelitian (Anwar \& Hasan, 2015) yang hanya dapat memaksimalkan offered traffic pada satu grup. Offered traffic pada proritas dapat dirumuskan sebagai berikut:

dimana,

$$
G=G_{h}+G_{m}
$$

$$
\begin{aligned}
G_{h} & =\frac{M_{h}}{N_{h}} \\
G_{m} & =\frac{M_{m}}{N_{m}}
\end{aligned}
$$

$G_{h}$ dan $G_{m}$ merupakan offered traffic manusia dan mesin.

$M_{h}$ dan $M_{m}$ merupakan jumlah user manusia dan mesin.

$N_{h}$ dan $N_{m}$ merupakan jumlah time -slot manusia dan mesin. 


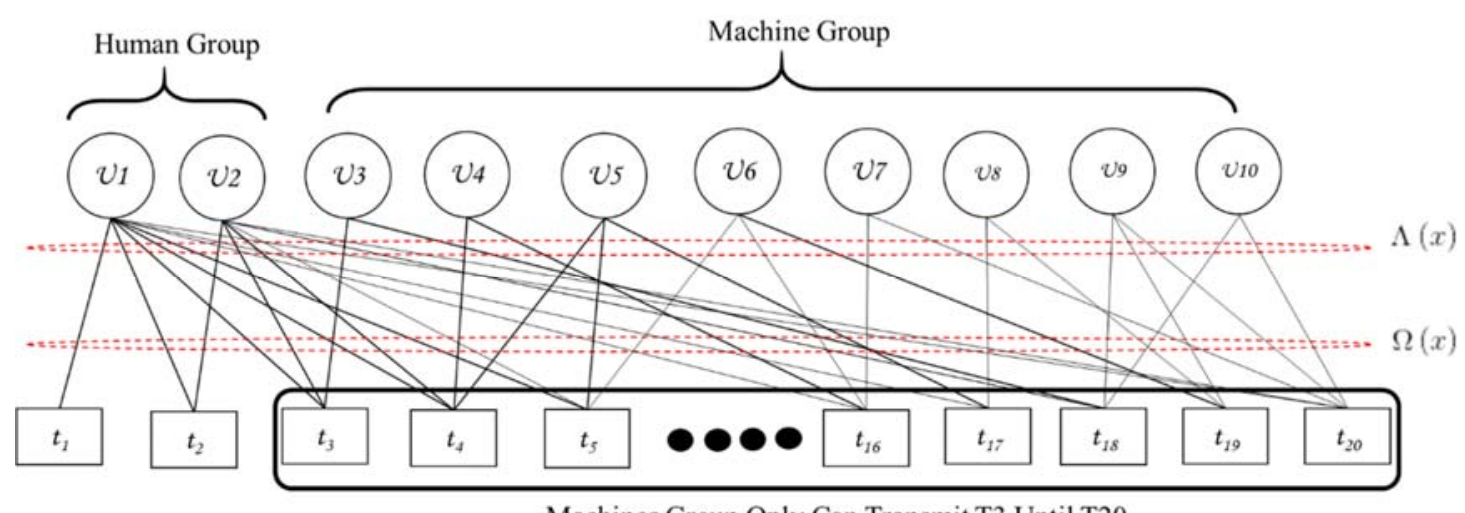

Machines Group Only Can Transmit T3 Until T20

Gambar 3. Bipartite-graph CRA dengan Prioritas Manusia

Packet-loss Rate (PLR) merupakan perbandingan sejumlah paket yang gagal dideteksi dengan total paket yang dikirim yang bisa disebabkan hilang diperjalanan atau diterima tapi tidak berhasil dideteksi (Kythe, Prem, 2012).

$$
P_{L}=\frac{b \prime}{b}
$$

Dimana $b^{\prime}$ merupakan jumlah informasi yang diterima pada receiver setelah dilewatkan kanal dan $b$ adalah informasi awal.

Throughput didefinisikan sebagai rasio dari jumlah paket benar diterima (tanpa error) dengan jumlah total paket yang dikirimkan termasuk paket yang salah yang dinyatakan dengan

$$
\begin{aligned}
& T_{h}=G_{h} *\left(1-P_{L}^{h}\right) \\
& T_{m}=G_{m} *\left(1-P_{L}^{m}\right)
\end{aligned}
$$

dimana $P_{L}^{h}$ adalah PLR grup manusia dan $P_{L}^{m}$ adalah PLR grup mesin. Jaringan super padat dengan teknik prioritas dikatakan berhasil apabila throughput pada grup manusia lebih tinggi dibandingkan dengan grup mesin. Total throughput dari teknik prioritas ini adalah penjumlahan antara throughput grup manusia dan mesin sehingga throughputyang dihasilkan dengan teknik prioriritas ini juga lebih tinggi dibandingkan dengan penelitian (Anwar \& Hasan, 2015) yang tanpa menggunakan teknik prioritas dan pembagian user.

\subsection{Degree Distribution pada User Node (UN) dan Slot Node (SN)}

Degree distribution ini yang menjadi ciri utama dari teknik multiple access CRA. Degree distribution merupakan distribusi banyaknya transmisi dari user dan menjamin proses berlangsungnya transmisi secara terus-menerus tanpa adanya error dengan menggunakan bantuan Successive Interference Cancellation (SIC) di sisi receiver. Dalam SIC terjadi cancel interferensi yang berkelanjutan sampai mendapatkan degree satu yang artinya user yang berada pada time-slot tersebut sudah terdeteksi.

Meskipun slot node tidak dapat didesain dan dikontrol karena jumlah time-slot yang sangat tidak terbatas, namun pada user node yang jumlahnya besar dapat didesain dan dikontrol dengan menggunakan degree distribution. Degree distribution merupakan distribusi banyaknya transmisi dari user, digunakan untuk mendapatkan throughput yang tinggi dan 
untuk menjamin keberlangsungan SIC dapat berjalan terus sampai mendapatkan degree satu sehingga semua user dapat terdeteksi. Degree distribution pada user node grup manusia berdasarkan node-perspective diekspresikan pada polynomial sebagai berikut

$$
\Lambda^{H}(x)=\sum_{\ell=2}^{L} \Lambda_{\ell}^{H} x^{\ell}
$$

dimana $\Lambda_{\ell}^{H}$ merupakan fraction dari UN manusia yang memiliki degree $\ell$.

Untuk menganalisis performansi jaringan menggunakan EXIT chart memerlukan degree distribution berdasarkan edge-perspective yaitu turunan pertama dari node-perspective degree distribution dibagi dengan turunan pertama node-perspective dengan memasukkan nilai $=1$. Degree distribution pada UN grup manusia berdasarkan edge-perspective diekspresikan sebagai berikut (Ni'amah, Anwar, Ramatryana, 2018)

$$
\lambda^{H}(x)=\frac{\Lambda^{\prime}(x)}{\Lambda^{\prime}(1)}=\sum_{\ell=0}^{L} \lambda_{\ell}^{H} x^{\ell-1}
$$

Persamaan degree distribution tersebut juga diterapkan pada grup mesin $\Lambda^{M}$ untuk nodeperspective dan $\lambda^{M}(x)$ untuk edge-perspective. Dari persamaan degree tersebut rate pada manusia dan mesin juga dapat ditentukan. Rate untuk grup manusia dengan menggunakan repetition codes diekspresikan sebagai berikut (Ni'amah, Anwar, Ramatryana, 2018)

$$
R_{h}=\frac{1}{\sum_{h=2}^{n h} \Lambda^{H} n^{H}}
$$

Sama hal nya rate untuk grup mesin diekspresikan dengan $R_{m}$.

Degree distribution pada SN, dengan akprosimasi probabilitas pada SN yang memiliki degree d. Degree distribution pada SN diekpresikan dengan:

$$
\psi_{d}=\left(\begin{array}{c}
M_{h} \\
d_{h}
\end{array}\right)\left(\begin{array}{c}
M_{m} \\
d_{m}
\end{array}\right)\left(\frac{G_{h}}{R_{h} M_{h}}\right)^{d}\left(\frac{G_{m}}{R_{m} M_{m}}\right)^{d}\left(1-\frac{G_{h}}{R_{h} M_{h}}\right)^{M_{h}-d_{h}}\left(1-\frac{G_{m}}{R_{m} M_{m}}\right)^{M_{m}-d_{m}}
$$

dimana $d=d_{h}+d_{m}$. Polynomial degree distribution SN diekspresikan dengan

$$
\begin{aligned}
& \Omega(x)=\sum_{d=0}^{M} \psi_{d} x^{d}=\left(1-\frac{G_{h}}{R_{h} M_{h}}\left(1-x_{h}\right)\right)^{M_{h}}\left(1-\frac{G_{m}}{R_{m} M_{m}}\left(1-x_{m}\right)\right)^{M_{m}} \\
& \approx \exp \left\{-\left(\frac{G_{h}}{R_{h}}\right)+\left(\frac{G_{m}}{R_{m}}\right)+\frac{G_{h}}{R_{h}} x_{h}+\frac{G_{m}}{R_{m}} x_{m}\right\}
\end{aligned}
$$

dimana $x=x_{h}+x_{m}$. Karena SN jumlahnya tidak terbatas sehingga degree distribution SN tidak dapat didesain atau dikontrol oleh karenannya menggunakan polynomial eksponensial.

\subsection{Repetition Codes}

Penelitian ini mengusulkan skema CRA menggunakan repetition codes untuk memprioritaskan data komunikasi manusia dibanding mesin. Kelebihan dari repetition codes adalah low complexity dan simpel dalam melakukan desain dan dianalisis karena satu bit informasi/paket digandakan untuk dikirimkan ke penerima sehingga paket yang dikirimkan dari pengirim akan sampai dipenerima sesuai dengan paket yang dikirimkan. Repetition codes $\left(n_{h}, 1\right)$ artinya paket diulang atau ditransmiikan sebanyak $n_{h}$ kali. Repetition codes cocok digunakan untuk sensor-sensor yang hanya membutuhkan data rate yang rendah karena memiliki rate lebih kecil dari 0,5 (Abbas, Shirvanimoghaddam, 2017). 
Degree distribution pada repetition codes sama seperti Persamaan (11). Erasure probabilitas yang keluar dari UN-manusia pada repetition codes diekspresikan sebagai berikut:

$$
q^{h}=\sum_{\ell=2}^{n_{c}} \lambda_{\ell}^{h}\left(p^{h}\right)^{\ell-1}
$$

dimana $\lambda_{\ell}^{h}$ adalah fraksi UN pada edge-perspective. Sama halnya dengan erasure probability pada grup mesin yaitu $q^{m}$. Repetition codes beroperasi pada rate $R \leq \frac{1}{2}$, dan rate $R>\frac{1}{2}$ untuk kode maximum distance separable (MDS), repetition codes disimbolkan dengan $\left(n_{h}, 1\right)$ dan kode MDS disimbolkan dengan $\left(n_{h}, k\right)$ (Anwar, Astuti, 2018).

\subsection{Binary Erasure Channel(BEC)}

Penelitian ini menggunakan kanal BEC untuk dapat menghasilkan EXIT chart. Dalam suatu link komunikasi, terdapat kemungkinan bahwa data yang diterima oleh receiver mengandung data yang salah (error) (Shokrollahi, 2006), Gambar 4 menunjukkan BEC, dengan erasure probability $P_{r}$ yaitu probabilitas data $x$ hilang dalam transmisi. BEC memiliki nilai $P$ yang biasanya berkisar pada $0 \leq p \leq 1 / 2$, dengan model masukan yaitu $x_{1}$ dan $x_{2}$ dan tiga keluaran yaitu $y_{1}, y_{2}$ dan $y_{3}$. Jika dikirimkan paket " 0 " probabilitas yang diterima adalah " $\mathrm{e}$ ", hal yang sama berlaku untuk bit "1" (Kythe, Prem, 2012).

$$
\begin{array}{r}
x=0 \curvearrowright \begin{array}{r}
1-p \\
p
\end{array} \circ y=0 \\
x=1 \propto y=e \\
1-p \rightarrow \circ y=1
\end{array}
$$

Gambar 4. BEC dengan Erasure probability $p$

\subsection{Algoritma Decoding Successive Interference Cancellation (SIC) pada Repetition codes}

Algoritma decoding SIC dideskripsikan dengan algoritma yang ditunjukkan pada Gambar 5 dengan prosedur sebagai berikut (Ni'amah, Anwar, Ramatryana, 2018)

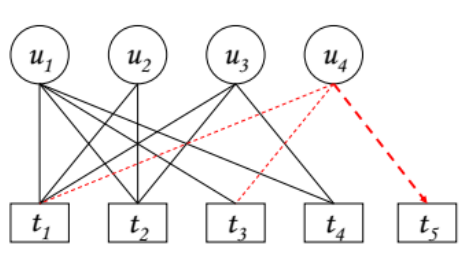

(a)

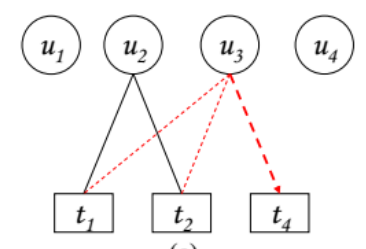

(c)

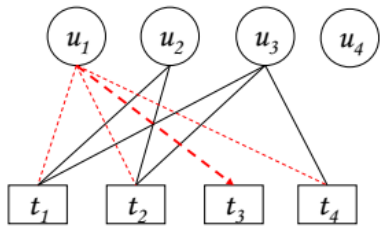

(b)

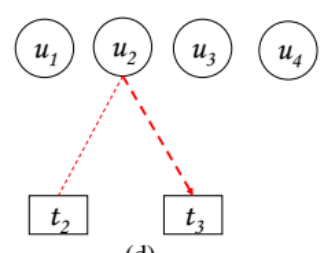

(d)

Gambar 5. Langkah-langkah Performansi Decoding yang Dilakukan BS pada Jaringan Super Padat menggunakan Repetition codes 
a. Langkah 1: Cari user $u_{i}$ yang terkoneksi dengan salah satu time -slots yang memiliki degree $d$. Hapus transmisi sinyal pada time -slot $t_{t}$ tersebut yang terhubung ke $u_{i}$ sehingga user $u_{i}$ tersebut semua transmisi sinyalnya berhasil dideteksi. Pada Gambar 5(a) user $u_{4}$ memiliki degree 1 yang terhubung dengan $t_{5}$ sehingga semua paket pada user $u_{4}$ telah diterima dengan benar tanpa terjadi error.

b. Langkah 2: Ulangi langkah pertama secara berulang sampai tidak lagi ditemukan degree $d=1$. Apabila tidak ditemukan lagi degree $d=1$ maka proses decoding berhenti seperti yang ditampilkan pada gambar 5(d) semua user berhasil dideteksi. Apabila proses decoding berhenti ketika masih ada user yang tidak memiliki degree 1 maka dikatakan "stoping set".

\section{HASIL DAN PEMBAHASAN}

\subsection{Analisis Hasil Simulasi EXIT CHART}

Penelitian ini melakukan evaluasi teknik multiple access CRA berdasarkan repetition codes sebanyak 150 user (30 user manusia dan 120 user mesin) dan jumlah time slot $(\mathrm{N}=200)$ dengan 50 kali percobaan untuk melihat perubahan degree distribution agar didapatkan degree distribution yang optimal. Untuk mendapatkan hasil yang efisien dan kualitas yang tinggi, dibutuhkan degree distibution yang optimal, untuk mendapatkan degree distribution optimal dilakukan optimalisasi dengan:

$$
\begin{array}{ll}
\text { maximize } & G=G_{h}+G_{m} \\
\text { subject to } & N \leq 200 \\
& T_{h} \geq T_{m} \\
& \delta \leq 0,1 \\
& f_{S N}\left(I_{A, S N}\right)>f_{U N}^{-1}\left(I_{E, U N}\right)
\end{array}
$$

dimana $\delta$ merupakan target minimum, $f_{S N}$ dan $f_{U N}$ merupakan kurva dari fungsi EXITSN dan UN.

Dari optimalisasi pada degree distribution didapatkan sub-optimal UN degree distribution untuk grup manusia dan mesin sebagai berikut:

$$
\begin{aligned}
& \Lambda^{H}(x)=0,3 x^{3}+0,7 x^{8} \\
& \Lambda^{M}(x)=0,6 x^{2}+0,4 x^{4}
\end{aligned}
$$

degree distribution pada grup manusia memiliki rate $R_{h}=0,153$ artinya pada grup manusia $30 \%$ dari $100 \%$ user manusia mentransmit sebanyak 3 kali ke time-slot secara random dan $70 \%$ lainnya men-transmit 8 kali ke time-slot secara random juga atau bebas ke seluruh timeslot manapun tanpa dibatasi dan pada grup mesin memiliki rate $R_{m}=0,375$ dimana $60 \%$ dari $100 \%$ pada user mesin mentransmit sebanyak 2 kali ke time-slot secara random dan 40\% lainnya men-transmit sebanyak 4 kali ke time-slot secara random namun hanya dapat mentransmit ke time-slot yang dikhususkan untuk grup mesin, untuk offered traffic pada grup manusia $G_{H}=0,15$ dan grup mesin $G_{m}=0,75$. Rate pada grup manusia lebih kecil dibandingkan dengan rate pada grup mesin karena bertujuan untuk memprioritaskan manusia, rate yang lebih rendah memiliki paket data loss yang rendah sehingga error pada pada paket yang dikirimkan kecil dan throughput yang ditinggi dibandingkan dengan rate yang tinggi memiliki paket data loss yang tinggi dan throughput yang lebih rendah. 
Untuk mendesain degree distribution yang optimal membutuhkan analisis EXIT chart berdasarkan UN dan SN edge-perspective degree distribution. Karena pada penelitian ini menggunakan dua grup maka diperlukan proyeksi EXIT chart. Pada proyeksi EXIT chart, time -slot pada CRA dipengaruhi oleh iterasi grup manusia dan iterasi grup mesin. Kurva EXIT antara UN-grup manusia dengan time -slot yang dipengaruhi oleh iterasi grup mesin disebut dengan proyeksi SN-mesin vs UN-manusia karena time -slot dari UN-grup manusia juga dipengaruhi oleh time -slot dari grup mesin, sebaliknya kurva EXIT antara UN-grup mesin dengan time -slot yang dipengaruhi oleh iterasi grup manusia disebut dengan proyeksi-SNmanusia vs UN-mesin.

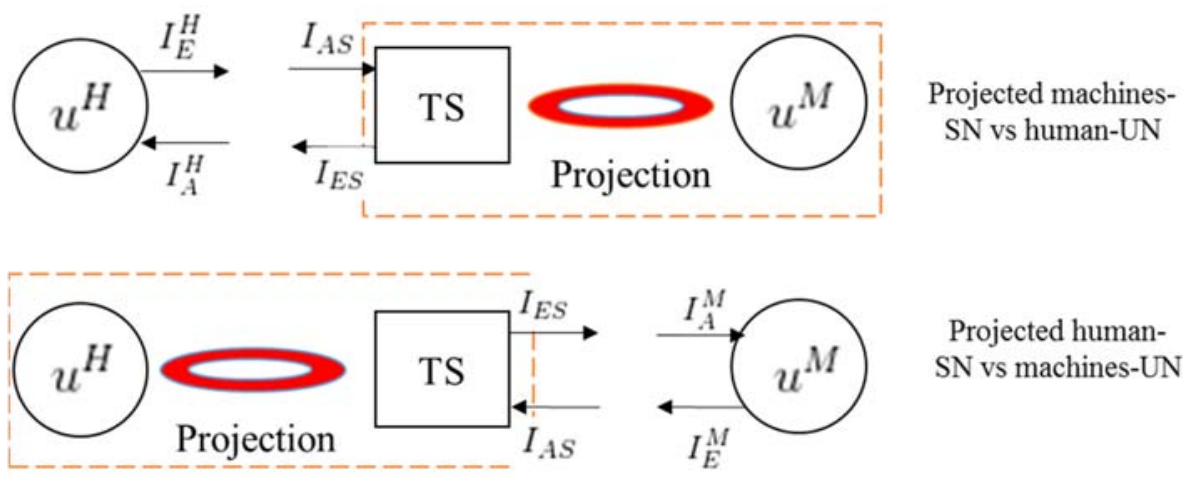

Gambar 6. Iterasi untuk Proyeksi EXIT Chart Grup Manusia dan Mesin

Penelitian ini didesain pada lapisan network dari OSI layer, dimodelkan dengan menggunakan kanal BEC sehingga diasumsikan paket yang tabrakan (collided) dihapus. Fungsi EXIT chart diekspresikan dengan menggunakan mutual information untuk grup manusia mutual informasi diekspresikan dengan:

$$
\begin{aligned}
& I_{E, U N}^{H}=1-q^{h} \\
& I_{A, U N}^{H}=1-p^{h}
\end{aligned}
$$

dimana $I_{E, U N}^{H}, I_{A, U N}^{H}$ adalah extrinsic mutual information dan apriori mutual information pada grup UN-manusia, $p^{h}$ dan $q^{h}$ adalah erasure probabilitas yang masuk dan keluar keluar ke/dari grup UN-manusia. Mutual informasi ini juga diterapkan untuk grup mesin $I_{E, U N}^{M}, I_{A, U N}^{M}$.

Arah $p^{h}$ dan $q^{h}$ diilustrasikan pada Gambar 3 begitu juga dengan grup mesin $p^{m}$ dan $q^{m}$. Hubungan $p^{h}$ dan $q^{h}$ diekspresikan untuk UN dan SN.

$$
q^{h}=\lambda^{H}\left(p^{h}\right)
$$

dan

$$
1-p^{h}=\omega^{H}\left(1-q^{h}\right) \cdot \omega^{M}\left(1-q^{m}\right)=\exp \left\{-\frac{G_{h}}{R_{h}}\left(1-q^{h}\right)-\frac{G_{m}}{R_{m}}\left(1-q^{m}\right)\right\}
$$


Rumus tersebut juga diterapkan pada grup mesin dengan erasure probabilitas $q^{m}$ dan $p^{h}$.

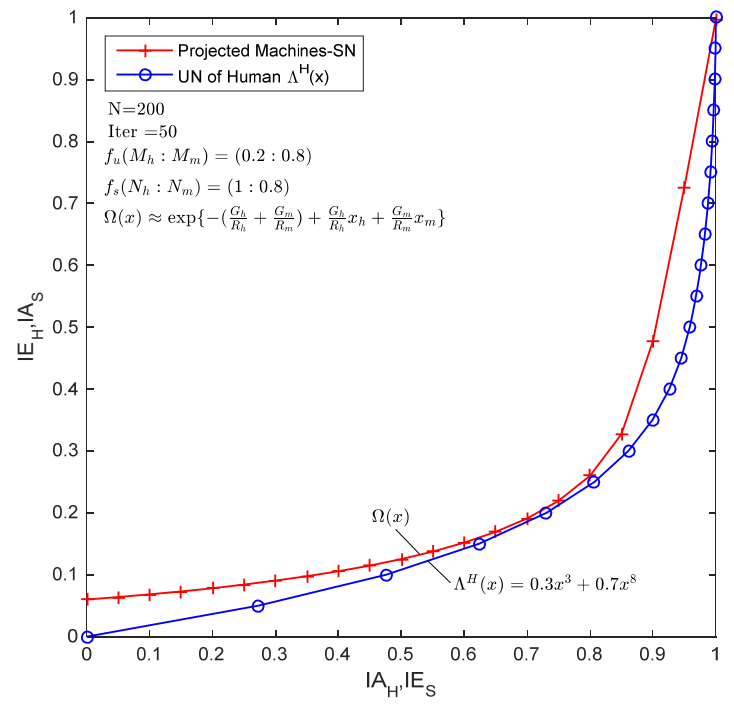

(a)

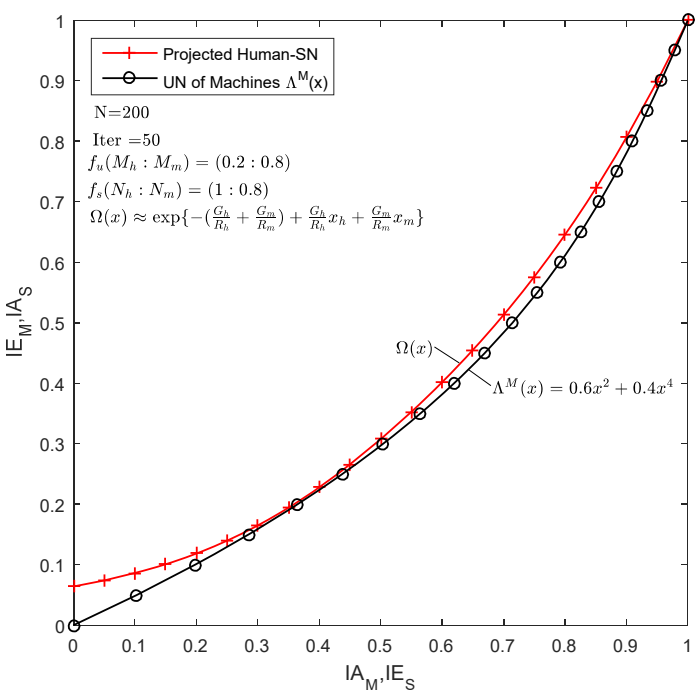

(b)

\section{Gambar 7. Proyeksi EXIT Chart pada: (a) SN-Mesin terhadap UN-Grup Manusia (b) SN Grup Manusia terhadap UN-Mesin yang Memiliki Gap yang Kecil Menunjukkan Degree Distribusi yang Optimal}

Kurva EXIT dievaluasi pada bipartite graph untuk grup manusia dan mesin dengan jumlah time slot $(\mathrm{N}=200)$ dengan 50 iterasi. Gambar 7 menunjukkan proyeksi EXIT chart, kurva EXIT pada grup manusia dan grup mesin UN $\Lambda^{H}(x), \Lambda^{M}(x)$ ditampilkan dengan tanda bulat "o" dan proyeksi antara SN-mesin dan SN-manusia ditampilkan dengan tanda positif "+". Kurva EXIT pada UN-manusia dan proyeksi antara SN-mesin dan manusia memiliki jarak (gap) yang kecil sehingga memiliki loss rate yang kecil begitu juga dengan grup mesin kurva EXIT antara UNmesin dan proyeksi SN-manusia dan mesin memiliki jarak (gap) yang kecil juga sehingga memiliki loss rate yang kecil juga sehingga baik proyeksi EXIT chart pada grup manusia maupun mesin sama-sama memiliki loss rate yang kecil dan degree distribution yang diusulkan pada grup manusia dan mesin juga bisa digunakan untuk jaringan masa depan yang super padat.

\subsection{Analisis Hasil Simulasi Packet-loss Rate (PLR)}

Penelitian ini menggunakan data UN degree distribution (manusia dan mesin) dari nodes perspective yaitu hasil analisis EXIT chart untuk menampilkan PLR secara simulasi. Untuk mengeksploitasi kedinamisan kanal fading dari fakta bahwa suatu edge dikatakan drop atau menghilang ketika daya terima $\gamma=|h|^{2}$ dibawah power threshold $T_{h}$, dengan probabilitas sebagai berikut:

$$
P_{r}\left(\gamma \leq T_{h}\right)=1-e^{-\frac{T_{h}}{r}}
$$

untuk kesederhaan analisis $T_{h}=0,25$.

Gambar 8 menunjukkan kurva PLR untuk degree distribusi $\Lambda^{H}(x), \Lambda^{M}(x)$ dengan $\mathrm{N}=200$ dan perbandingan manusia dan mesin 20:80. Offered traffic pada PLR $10^{-2}$ grup manusia tanpa fading diperoleh $\mathrm{G}=0,7$ paket/slot dan dengan fading $\mathrm{G}=0,69$ paket/slot dan untuk grup mesin 
tanpa fading dengan $\mathrm{G}=0,56$ paket/slot dan dengan fading $\mathrm{G}=0,42$ paket/slot. PLR untuk grup manusia lebih bagus dibandingkan dengan grup mesin begitu juga dengan adanya fading tetap PLR grup manusia yang lebih bagus dibandingkan mesin dan untuk kasus PLR tanpa fading lebih bagus dibandingkan dengan adanya fading.

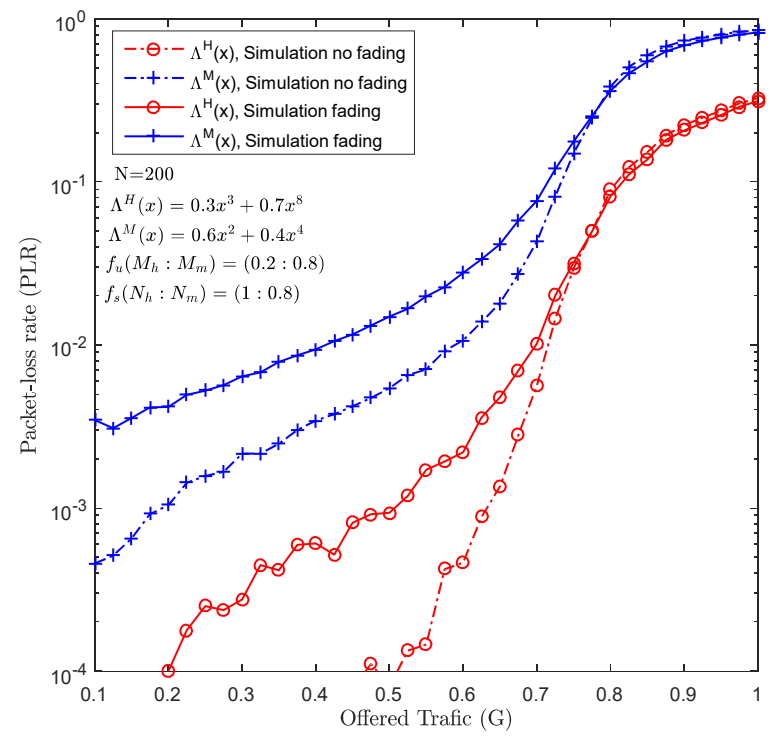

\section{Gambar 8. Grafik Performansi PLR dengan Prioritas untuk N=200}

\subsection{Analisis Hasil Simulasi Throuhgput}

Penelitian ini menggunakan data hasil simulasi PLR. Berdasarkan PLR yang didapatkan pada Gambar 8, throughput suatu network dikalkulasikan menggunakan Persamaan (5) dan didapatkan grafik throughput seperti yang ditunjukkan pada Gambar 9.

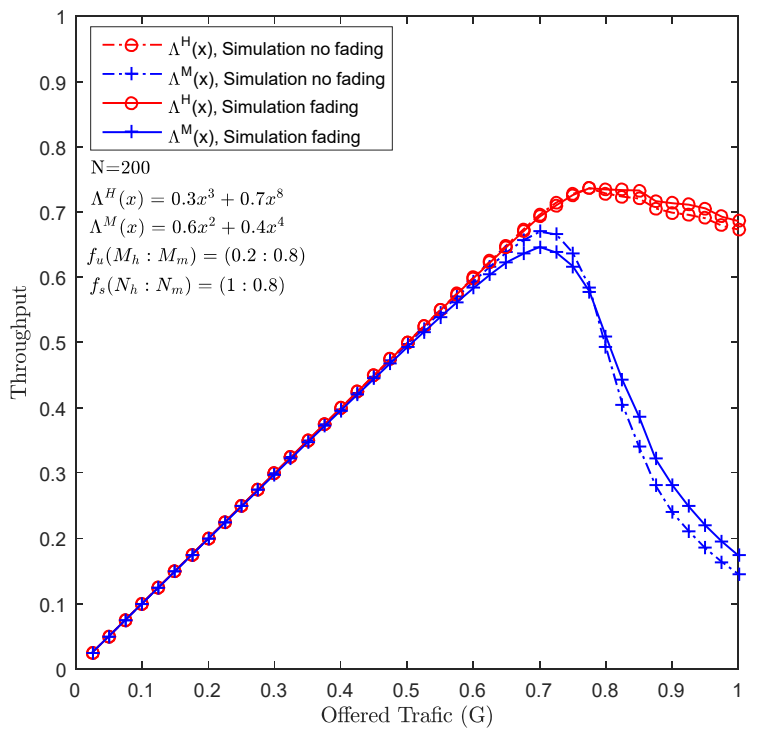

Gambar 9. Grafik Performansi Throughput dengan Prioritas untuk $\mathbf{N}=200$ 
Pada Gambar 9 terlihat jelas puncak throughput untuk simulasi degree distribution tanpa fading dengan $\mathrm{N}=200$ pada $\mathrm{G}=0,775$ paket/slot dan dengan fading $\mathrm{G}=0,736$ paket/slot pada grup manusia dan untuk grup mesin tanpa fading $\mathrm{G}=0,669$ paket dan dengan fading $\mathrm{G}$ $=0,646$ paket. Throughput pada grup manusia lebih tinggi dibandingkan dengan grup mesin baik yang tanpa fading maupun ada fading yang mengindikasikan kesuksesan pada komunikasi data grup manusia lebih tinggi dibandingkan dengan grup mesin.

\section{KESIMPULAN}

Penelitian ini telah mengusulkan teknik multiple access CRA menggunakan repetition codes untuk memberikan prioritas pada data komunikasi manusia di jaringan super padat. Dievaluasi dengan menggunakan proyeksi EXIT chart untuk mendapatkan degree distribution yang paling optimal untuk grup manusia dan mesin. Performansi dilakukan dengan menggunakan simulasi komputer dan menunjukkan bahwa dengan menggunakan proyeksi EXIT chart didapatkan sub-optimal degree distribution untuk grup manusia $\Lambda^{H}(x)=0,3 x^{3}+0,7 x^{8}$, dan untuk grup mesin $\Lambda^{M}(x)=0,6 x^{2}+0,4 x^{4}$. Evaluasi performansi pada teknik prioritas juga dilihat dari parameter throughput yang dihasilkan pada grup manusia tanpa fading $T_{h}=0,775$ paket $/ \mathrm{s} / \mathrm{ot}$ dengan fading $T_{h}=0,736$ paket $/$ slot dan untuk grup mesin tanpa fading $T_{m}=0,669$ paket $/$ slot dan dengan fading $T_{m}=0,646$ paket $/$ slot.

Dapat disimpulkan dengan melakukan teknik priotitas pada grup manusia bahwa (i) keberhasilan data komunikasi manusia dibandingkan dengan mesin yang dilihat dari gap atau jarak antara kurva user node-manusia dengan slot node-mesin dan sebaliknya pada proyeksi EXIT chart yang sangat kecil sehingga menunjukkan error yang kecil (ii) Performansi throughput pada grup manusia lebih tinggi dibandingkan grup mesin walaupun ada pengaruh dari fading dan (iii) Performansi PLR pada manusia juga lebih baik dibandingkan grup mesin walaupun ada pengaruh dari fading.

\section{UCAPAN TERIMA KASIH}

Penulis mengucapkan terima kasih kepada bapak Dr. Eng Khoirul Anwar yang telah memberikan ide, masukan-masukan dan bimbingan yang sangat membantu penulis dalam menyelesaikan penelitian ini. Terima kasih juga kepada Lembaga Penelitian dan Pengabdian Masyarakat (LPPM) Institut Teknologi Telkom Purwokerto yang telah mendukung penelitian ini.

\section{DAFTAR RUJUKAN}

Abbas, R., Shirvanimoghaddam, M., Li, Y., \& Vucetic, B. (2017). Random Access for M2M

Communications with QoS Guartantees. IEEE Transactions on Communication, 90 (6778), 43-53.

Anwar, K., \& Astuti, R. P. (2016). Finite-length Analysis for Wireless Super-dense Networks Exploiting Coded Random Access Over Rayleigh Fading Channels. IEEE Asia Pacific Wireless and Mobile Conference (APWIMOB). (pp. 1-6). Bandung.

Anwar, K., Juansyah, Syihabuddin. B., \& Adriansyah N. M. (2017). Coded Random Access with Simple Header Detection for Finite Length Wireless 
IoT Networks. Eighth International Workshop on Signal Design and Its Applications in Communications (IWSDA). (pp. 94-98). Japan.

Kythe, Dave K \& Prem, K. (2012). Algebraic and Stochastic Coding Theory. CRC Press Taylor \& Francis Group.

Ericsson. (2011). More Than 50 Billion Connected Devices. Ericsson Whitepaper. (pp 1-12).

Hasan, M.N., \& Anwar.K. (2015). Massive Uncoordinated Multiway Relay Networks with Simultaneous Detections. IEEE International Conf. on Comm. Workshop (ICCW), (pp. 2175-2180). London.

ITU-R. (2015). IMT Vision Framework and Overall Objective of the Future Development of Int for 2020 and beyond.

Liva, G. (2011). Graph-based analysis and optimization of contention resolution diversity slotted ALOHA. IEEE Trans. on Communications, 59(2), 477-487.

Ni'amah, K., Ramatryana. I. A \& Anwar. K. (2018). Coded Random Access Prioritizing Human Over Machines for Future IoT Networks. International Conference on Telematics and Future Generation Network (TAFGEN), (pp. 19-24). Malaysia.

Shokrollahi, A. (2006). Raptor Codes. IEEE Trans. on Information Theory, 52(6), 2551-2567.

Toni, L., \& Frossard, P. (2015). Prioritized Random MAC Optimization Via Graph-based Analysis. IEEE Transactions on Communication, 63(12), 1-12. 